\title{
The failure of the Russian global license proposal and the future of alternative remuneration systems
}

Dr Gaetano Dimita ${ }^{1} \&$ Ruslan Nurullaev*23

\begin{abstract}
As rights holders, courts, and policy makers worldwide struggle with the question of copyright infringement and the potential liability of internet service providers (ISPs) worldwide, Russia developed - and subsequently abandoned - a proposal for the creation of a global license to be imposed on ISPs which would allow for rights holders to be compensated for copyrightinfringing activities carried out through those ISPs.

Russia is not the first jurisdiction to look at a global license as solution to the wide spread of copyright infringements online. By analysing the Russian proposal for a global license, this article addresses the sustainability of such a model on a wider scale by analysing the legal implications this may cause. In this context, this article will address the Russian proposal's legislative history before moving into a substantive discussion about the synergies between legal justifications and merits of a global license.
\end{abstract}

Keywords: copyright; copyright policy; alternative remuneration systems; global license; three-step test.

\section{Introduction}

This article briefly analyses the evolution of ISP liability regulation in Russia to provide a framework to the latest proposal of a global license which sought to tackle the issue of online copyright infringement by enabling internet users to freely share and download creative works in

\footnotetext{
${ }^{1}$ Senior Lecturer in International Intellectual Property Law, Centre for Commercial Law Studies, Queen Mary University of London

2 Junior Research Fellow, National Research University Higher School of Economics, 3 Bolshoy Tryokhsvyatitelsky Pereulok, Moscow, Russia, 123022. Email address: rusnur@gmail.com

3 The authors are very grateful to Beata Sobkow for her invaluable contribution to this article. The article was prepared within the framework of the Basic Research Program at the National Research University Higher School of Economics (HSE) and supported within the framework of a subsidy by the Russian Academic Excellence Project '5100'. 
exchange for a small fee payable together with the internet access fee. The paper looks into the details of the Russian proposal, the arguments pro and against, and it's historical precedents (the French licence globale and German Kultur flat-rate) to assess the conformity of such alternative remuneration systems with international obligations and their possible future.

\section{ISP liability: the Russian context}

In Russia, the development of the rules regulating ISP liability for infringement of intellectual property rights (IPR) committed by users can be broken down into two stages. Pre2013, ISP liability for IPR infringements was scarcely regulated by legislation and largely to be found in seminal decisions of the arbitration courts. ${ }^{4}$ This has changed in 2013, when the Federal Law No. 187-FZ, ${ }^{5}$ often referred to as the Anti-piracy Law, entered into force and introduced into Russian legislation rules regulating ISP liability for IPR infringement as well as created a procedure for blocking websites facilitating copyright infringement.

Before 2013, the rules relating to ISP liability for copyright infringement could be gleaned from a number of arbitration courts' decisions, including the judgments in Content $i$ Pravo $v$ Masterhost and MetKom ${ }^{6}$ in which the right holder sued a provider of colocation services, and Top $7 v$ Softkey, Dignata Media, Agava-soft ${ }^{7}$ which concerned liability of a file-locker website administrator.

\footnotetext{
${ }^{4}$ Arbitration courts are the courts which exercise jurisdiction over commercial disputes in Russia. Not to be confused with arbitration as a form of alternative dispute resolution.

5 О внесении изменений в отдельные законодательные акты Российской Федерации по вопросам защиты интеллектуальных прав в информационно-телекоммуникационных сетях : Федеральный закон : 3 июля 2013 г. № 187-Ф3 [Federal Law on Amendment of Certain Legislative Acts of the Russian Federation Concerning the Issues of Protection of Intellectual Rights in Information and Telecommunications Networks dated 3 July 2013 No. 187-FZ] // Собр. законодательства Рос. Федерации. 2013. № 27. Ст. 3479.

${ }^{6}$ Постановление Президиума Высшего арбитражного суда Российской Федерации № 10962/08, Москва, 23 декабря 2008 г. [Decision of the Presidium of the Supreme Arbitration Court of the Russian Federation No. 10962/08, Moscow, 23 December 2008].

7 Постановление Президиума Высшего арбитражного суда Российской Федерации № 6672/11, Москва, 1 ноября 2011 г. [Decision of the Presidium of the Supreme Arbitration Court of the Russian Federation No. 6672/11, Moscow, 1 November 2011].
} 
In these cases, the Supreme Court of Arbitration ${ }^{8}$ drew up a list of factors which must be assessed when deciding the issue of ISP liability for IPR infringements committed by third parties. Among these factors were the degree of involvement of an ISP in the process of transfer of information and implementation by an ISP of preventive measures which stop IPR infringements.

On 1 August 2013, the Anti-piracy law came into force. This law introduced a new legal term: 'information intermediary', and regulated liability of such entities for IPR infringements. These changes are enshrined in the new Article 1253.1 of the Russian Civil Code. ${ }^{9}$

Although the aim of the Anti-piracy law was to set out the regulation of ISP liability for IPR infringements on the statutory level, the new law arguably came short of reaching this goal in several aspects.

For example, it is not entirely clear what entities can be considered information intermediaries as Article 1253.1 of the Civil Code does not contain a general definition. Instead, information intermediaries are defined by listing their specific types. Depending on the type of information intermediary, it will have to comply with different conditions to avoid liability for IPR infringements.

Furthermore, this classification is slightly different from the classifications provided in the United States' Digital Millennium Copyright Act (DMCA) ${ }^{10}$ or the European Union's ECommerce Directive. ${ }^{11}$ The classification provided in Article 1253.1 is less clear which, in turn, makes it more difficult to tell in advance what type of an information intermediary a particular ISP will be in each specific case. Being able to distinguish between different types of information intermediaries is important as different types of information intermediaries have to comply with different requirements to qualify for a safe harbour. Perhaps more importantly, Article 1253.1 does not explicitly provide safe harbours for certain types of information intermediaries.

Article 1253.1 also comes short of establishing rules for substantive liability of information intermediaries. Instead, Article 1253.1 merely states that the information intermediary can be

\footnotetext{
${ }^{8}$ The Supreme Arbitration Court had been the most senior arbitration court in Russia until its was disbanded in 2014 and cases formerly within its jurisdiction were transferred to the Supreme Court of Russia.

${ }^{9}$ Гражданский кодекс Российской Федерации. Часть четвертая : 18 декабря 2006 г. № 230-Ф3 [Civil Code of the Russian Federation, Part 4 dated 18 December 2006 No. 230-FZ] // Собр. законодательства Рос. Федерации. 2006. № 52 (Ч. 1). Ст. 5496.

1017 US Code $\S 512$.

${ }^{11}$ Directive 2000/31/EC of 8 June 2000 on certain legal aspects of information society services, in particular electronic commerce, in the Internal Market [2000] OJ L178/1 (E-Commerce Directive).
} 
found liable under the general rules of the Civil Code if its fault is established. The problem is that under the 'general rules' of the Civil Code, in order to infringe IPRs, it is usually necessary to use the work in question (e.g., to copy the work or make it available). However, information intermediaries do not normally use works themselves - the works are used (and infringements are committed) by users of the services provided by information intermediaries. As the Supreme Court of Arbitration observed in Content i Pravo v Masterhost and MetKom, a person who does not use a creative work cannot be held to infringe the authors' rights in respect of this work. Thus, it is not clear what the exact ground for liability of information intermediaries is when infringements are committed by users. Article 1253.1 also does not further explain what circumstances must exist for the ISP's fault to be established.

Finally, Article 1253.1 of the Civil Code makes availability of safe harbours dependent on the information intermediary's lack of actual or imputed knowledge about IPR infringements. At the same time, Article 1253.1 provides limited guidance on how such knowledge can be accessed.

In addition to creating a statutory framework for ISP liability, the Anti-piracy Law also introduced a right for right holders to request preliminary website blocking injunctions allowing them to expediently restrict access to a website used to commit infringements whilst they prepare to sue the website administrator for IPR infringement. ${ }^{12}$ Although initially preliminary website blocking injunctions were available only for protection of rights in video content, in 2015 their scope was expanded by the Federal Law No. 364-FZ to include other creative works with exception of photographs. ${ }^{13}$ The Federal Law No. 364-FZ also created a new procedure for permanent blocking of websites which repeatedly infringe authors' rights.

\footnotetext{
12 Об информации, информационных технологиях и о защите информации : Федеральный закон : 27 июля 2006 г. № 149-Ф3 [Federal Law on Information, Information Technologies and Protection of Information dated 27 July 2006 No. 149-FZ] // Собр. законодательства Рос. Федерации. 2006. № 31 (Ч. 1). Ст. 3448, ст. 15.6.

13 О внесении изменений в Федеральный закон "Об информации, информационных технологиях и о защите информации" и Гражданский процессуальный кодекс Российской Федерации : Федеральный закон : 27 ноября 2014 г. № 364-Ф3 [Federal Law on Amendment of the Federal Law “On Information, Information Technologies and Protection of Information" and the Civil Procedure Code of the Russian Federation dated 27 November 2014 No. $364-$ FZ] // Собр. законодательства Рос. Федерации. 2014. № 48. Ст. 6645.
} 
Website blocking is widely used by right holders: the Moscow City Court has granted more than 700 preliminary website blocking injunctions, ${ }^{14}$ permanent website blocking has been used against 15 largest BitTorrent-trackers. ${ }^{15}$

In 2017, website blocking measures available to right holders were further strengthened. Russian authorities can now block access to providers of VPN and other services which can be used by internet users to circumvent website blocking. ${ }^{16}$ Web search engines that show advertising to internet users in Russia have to delist from their search results links to website that have been previously blocked in accordance with Russian legislation. ${ }^{17}$ An expedited procedure for blocking copies of previously blocked websites has also been implemented. ${ }^{1819}$

As discussed, Russia has developed a legal framework which gives right holders access to a variety of measures to help them protect their IPRs and to stop and prevent IPR infringements: they can use the notice and takedown procedure, sue internet service providers, and apply for website blocking orders against websites facilitating IPR infringement. Alexander Zharov, the head of the Federal Service for Supervision in the Sphere of Telecom, Information Technologies and Mass Communications, the authority overseeing website blocking in Russia, reported that the antipiracy legislation was one of the reasons which helped the online video distribution industry to grow by $14.7 \%$ in $2015 .^{20}$

${ }^{14}$ Office of the United States Trade Representative, '2017 Special 301 Report' (Office of the United States Trade Representative ) <https://ustr.gov/sites/default/files/301/2017\%20Special\%20301\%20Report\%20FINAL.PDF> accessed 27 March 2018, 47.

15 'Александр Жаров (Роскомнадзор): «Сегодня всю нашу работу мы рассматриваем через призму уменьшения давления на предпринимательское сообщество»' [Alexander Zharov (Roskomnadzor): “Today all our work is considered in the light of reducing the pressure on the business community"'] (respectr.com, 4 February 2016) <http://www.rspectr.com/article/intervyu/aleksandr-zharov-roskomnadzor/> accessed 16 October 2016.

16 Об информации, информационных технологиях и о защите информации : Федеральный закон : 27 июля 2006 г. № 149-Ф3 [Federal Law on Information, Information Technologies and Protection of Information dated 27 July 2006 No. 149-FZ], ст. 15.8.

17 Об информации, информационных технологиях и о защите информации : Федеральный закон : 27 июля 2006 г. № 149-Ф3 [Federal Law on Information, Information Technologies and Protection of Information dated 27 July 2006 No. 149-FZ], ч. 2.1 ст. 15.6, ч. 5 ст. 15.6-1, ч. 6, 8 ст. 15.8.

18 Об информации, информационных технологиях и о защите информации : Федеральный закон : 27 июля 2006 г. № 149-Ф3 [Federal Law on Information, Information Technologies and Protection of Information dated 27 July 2006 No. 149-FZ], ч. 5 ст. 15.6-1.

${ }^{19}$ For more detailed discussion of the development of website blocking in Russia see Ruslan Nurullaev, 'Website blocking in Russia: recent trends' (2017) 33(2) Computer Law \& Security Review 211.

20 Александр Жаров, 'Тезисы выступления А.А. Жарова на тему «Опыт Российской Федерации по защите авторских прав в национальном сегменте сети "Интернет", [Alexander Zharov, 'Summary of the speech of A.A. 
On the other hand, current legislation does have its shortcomings. As discussed in this section, Article 1253.1 of the Civil Code does not clearly define and classify information intermediaries, the conditions for substantive ISP liability, and safe harbour requirements for different types of ISPs.

Website blocking also demonstrates limited effectiveness. After blocking of Rutracker, one of the largest BitTorrent index and tracker in Russia, despite the apparent reduction of the number of users, the file-sharing activity on the tracker decreased by no more than $10 \% .{ }^{21}$ More generally, not fewer than $65 \%$ of websites which have been blocked for users in Russia continue to operate. ${ }^{22}$

\section{Russia's global license proposal}

The Russia's Ministry of Culture experts stated that, in practice, the measures provided in the current framework are 'highly ineffective and do not allow to fundamentally resolve the problem of internet piracy'. ${ }^{23}$ Nikita Mikhalkov, the President of the Council of the Russian Union of Right-Holders (RUR), a collecting society for the private copying levy suggested that 'the current [online copyright enforcement] legislation is not working'. ${ }^{24}$

\footnotetext{
Zharov on the topic "Experience of the Russian Federation in protection of authors' rights in the national segment of the Internet"] (Роскомнадзор, 25 March 2016) <https://rkn.gov.ru/docs/03-21-2016_Tezisy_Kitaj_ZHarov.pdf> accessed 10 July 2016, 4.

21 Андрей Фролов, 'Администрация Rutracker признала падение посещаемости вдвое за год «вечной» блокировки' [Andrey Frolov, 'Administraction of Rutracker acknowledged decrease in website visits by fifty per cent after the year of "permanent" blocking'] (Vc.ru, 23 January 2017) <https://vc.ru/21481-rutracker-admin50percent> accessed 27 March 2018.

22 Дада Линделл, Анна Балашова, Ирина Ли, 'В России продолжили работать 65\% заблокированных сайтов' [Dada Lindell, Anna Balashova, Irina Li, ' $65 \%$ of blocked websites continue to operate in Russia'] ( $Р Б K$, 16 February 2017) <https://www.rbc.ru/technology_and_media/16/02/2017/588619a59a79473089dbad69> accessed 29 March 2018.

23 'Сводный отчет о проведении оценки регулирующего воздействия к проекту федерального закона «О внесении изменений в Гражданский кодекс Российской Федерации в части совершенствования оборота результатов интеллектуальной деятельности в информационно-телекоммуникационных сетях» [Summary report on the conduct of the assessment of the regulatory impact of the draft Federal Law "On Amendment of the Civil Code of the Russian Federation with Regard to Improving of Circulation of the Results of Intellectual Activity in Information-Telecommunication Networks"] (Федеральный портал проектов нормативных правовых актов) <regulation.gov.ru/Files/GetFile?fileid=5b47c1c3-e0d4-47eb-b5ad-5c61e32cf552> accessed 29 March 2018.

${ }^{24}$ Матвей Алексеев, Светлана Поворазнюк, “«Мы ни у кого ничего не хотим отбирать» Никита Михалков и Сергей Федотов о глобальной лицензии в интернете' [Matvey Alexeev, Svetlana Povoraznyuk, "'We do not want to take anything from anyone" Nikita Mikhalkov and Sergey Fedotov on global license on the internet'] (Lenta.ru, 6 April 2015) <https://lenta.ru/articles/2015/04/06/mikhalkovfedotov/> accessed 29 March 2018.
} 
Dissatisfaction with the current legal framework motivated the RUR to prepare their 'global license' proposal. ${ }^{25}$ The main idea behind this proposal was to allow internet users to freely share and download creative works online in exchange for a small fee payable together with the internet access fee. The accumulated money would then be distributed among right holders, taking into account the frequency of use of their works.

Despite the fact that the global licence proposal was ultimately withdrawn, this being one of the few cases where, on a national level, a model of an alternative compensation system was debated, the Russian global license proposal merits a closer scrutiny. It should be noted that the global license proposal is not the first of its kind - similar initiatives have been suggested before, in particular, in France in 2005 and in Germany in 2009 (these proposals will be looked at in more detail in the next section of this paper). The fact that the global license proposal appeared in Russia in 2014 suggests that there is still a lack of consensus about the application of copyright laws online and the role of ISPs in facilitating monetisation of copyright works for the benefit of right holders. This is probably true not only for Russia, but also for the European Union where the recently proposed new Copyright Directive may impose additional obligations on online platforms that use user-generated content.

In October 2014, Nikita Mikhalkov (who earlier successfully lobbied for the adoption of the private copying levy in respect of blank carriers) presented the concept of the global license, 'the new instrument of [IPR] management on the web' ${ }^{26}$ to the President who then ordered the Russian Government to assess the feasibility of the scheme. ${ }^{27}$ A draft of the law was published for public consultation in February 2014 by the Ministry of Culture. ${ }^{28}$ It suggested to implement the

${ }^{25}$ The draft of the proposed global license legislation is available at http://regulation.gov.ru/projects\#npa=19565 (Global License Draft Law).

26 Анастасия Голицына, Ксения Болецкая, 'Михалков готовит налог на пиратство' [Anastasiya Golitsyna, Kseniya Boletskaya, 'Mikhalkov is preparing a piracy tax'] (Vedomosti, 31 October 2014) <https://www.vedomosti.ru/newspaper/articles/2014/10/31/mihalkov-gotovit-nalog-na-piratstvo> accessed 29 March 2018.

27 Анастасия Голицына, 'Шувалов поручил разработать законопроект об авторском сборе в интернете по предложению Михалкова' [Anastasiya Golitsyna, 'Shuvalov ordered to prepare a draft law on copyright levy for the internet based on Mikhalkov's proposal'] (Vedomosti, 10 November 2014) <https://www.vedomosti.ru/business/articles/2014/11/10/shuvalov-poruchil-razrabotat-zakonoproekt-na-osnove> accessed 29 March 2018.

28 Дарья Луганская, ‘Законопроект об антипиратском сборе опубликован для обсуждения’ [Darya Luganskaya, 'Draft law on the antipiracy levy has been published for discussion'] (РБK, 20 February 2014) <https://www.rbc.ru/technology_and_media/20/02/2015/54e740bc9a7947b21f91cc76> accessed 29 March 2018. 
global license scheme by amending the provisions of Part 4 of Russia's Civil Code which regulates intellectual property.

The global license was to be granted by a state-accredited collective rights management organisation (ACRMO) ${ }^{29}$ and was intended to cover musical works, literary works, audio-visual works, ${ }^{30}$ recorded performances, and sound recordings. ${ }^{31}$ The draft law did not, however, bring other frequently used works such as compilations or computer programs within the scope of the global licence.

This license was to initially apply to works of all right holders (whether national or foreign), even if they did not authorise the ACRMO to provide global licenses for their works. ${ }^{32}$ Right holders who did not wish to participate in the global license scheme could later apply to the ACRMO to opt out of the scheme. The ACRMO would be required to exclude the works of such right holders from the global license regime within one month of receiving a request. ${ }^{33}$

The global license was to grant internet users the right to copy creative works into the memory of a personal computer as well as the right to make such works available. ${ }^{34}$ By entering into an internet access agreement with an internet access provider a person would be presumed to have agreed to acquire a global license (internet users would not be able to refuse its acquisition). Termination of the internet access agreement would then also mean the termination of the global license.

All internet users would be required to pay additional fees to their internet access providers to cover the global licenses. Sergey Fedotov, the then General Director of the Russian Authors' Society (another collective rights management organisation which supported the global license proposal) stated that global license fees could amount to five per cent of the cost of internet access

\footnotetext{
${ }^{29}$ Article 1(4) of the Global License Draft Law.

30 ibid.

31 ibid, Article 1(5).

32 ibid, Article 1(3).

33 ibid.

${ }^{34}$ ibid, Article 1(4).
} 
services and mentioned the monthly payment of RUB 25 (circa $£ 0.31$ as of 27 March 2018) per one internet access services agreement. ${ }^{35}$

Internet access providers would be responsible for collecting the global license fees from users. They would also have to sign agreements with the ACRMO in order to transfer moneys received from users to the ACRMO; the form of the agreement being approved by the Government. ${ }^{36}$ The ACRMO was then to distribute the accumulated funds to right holders; distribution of funds being, again, regulated by the Government. ${ }^{37}$

Whilst the draft legislation was silent on this aspect, the Ministry of Culture proposed that remuneration could be distributed unevenly between right holders, depending on the type of creative work. This proposal was justified on the basis of different level of use of creative works. For example, in 2013, among the different types of downloaded content the share of use of audiovisual works was $54 \%$, musical works and sound recordings $38 \%$, and literary works $8 \%{ }^{38}$

The distribution of monies collected from internet access providers was to be based on a public register of creative works, established by the ACRMO ${ }^{39}$ This register would allow right holders to provide additional information on their works, and it would be ACRMO's responsibility to use reasonable endeavours to identify creative works and add them to the register. ${ }^{40}$

The Government was to adopt bylaws to regulate: (1) the requirements related to the information on creative works contained in the register; and (2) the process of online publication of such information. ${ }^{41}$

Internet access providers were to be required to 'create technical conditions" 42 facilitating the identification and assessment of creative works covered by the global licenses (probably

\footnotetext{
${ }^{35}$ Наталья Баринова, Александр Малахов, ‘Сергей ФЕДОТОВ: получается, что нет бесхозных денег’ [Natalyа Barinova, Alexander Malakhov 'Sergey FEDOTOV: it turns out that there is no ownerless money'] (TACC, 8 December 2014) <http://tass.ru/opinions/interviews/1630961> accessed 29 March 2018.

${ }^{36}$ Article 1(2) of the Global License Draft Law.

37 ibid, Article 1(4).

38 Дарья Луганская, 'Кликнул - плати' [Darya Luganskaya, 'Clicked - pay'] (РБК, 10 December 2014) <http://www.rbc.ru/newspaper/2014/12/10/56bd58499a7947299f72c5bf> accessed 29 March 2018.

${ }^{39}$ Article 1(4) of the Global License Draft Law.

${ }^{40}$ Article 1(1) of the Global License Draft Law.

41 ibid.

${ }^{42}$ ibid, Article 1(4).
} 
meaning the assessment of the use of such works), and they would be compensated for the respective expenses by the ACRMO. ${ }^{43}$ The draft law also stated that during the identification and assessment of creative works, users' right to protection of private life would have to be respected. ${ }^{44}$

The global license scheme was a radical measure which understandably created divisions. The scheme was supported by the Ministry of Culture (which coordinated the work on the draft law), collective rights management organisations, and right holders many of whom were affiliated with the collective rights management organisations. ${ }^{45}$

At the same time, the proposal brought together numerous (sometimes unexpected) opponents, including the Ministry of Communications, ${ }^{46}$ the Ministry of Economic Development, ${ }^{47}$ Federal Antimonopoly Service, ${ }^{48}$ internet companies and right holders, ${ }^{49}$ and a number of other entities and organisations all of which provided their objections to the proposal.

\subsection{Arguments in support of global licenses}

Those who supported global licenses relied on the fact that right holders are currently unable to adequately monetise their works online. This is true for a range of interconnected reasons: (1) users use content illegally and do not want to pay for it, (2) website owners publish content illegally in order to attract users and gain money from advertising, (3) internet access providers do not commit direct infringements, but generally profit from copyright infringements,

43 ibid.

44 ibid, Article 1(4).

45 Андрей Лукинов, Соня Соколова, Юрий Ильин, 'Глобальная лицензия: пиратство в масштабе Рунета' [Andrey Lukinov, Sonya Sokolova, Yuriy Ilyin, 'Global license: piracy on the scale of the Runet'] (3вуки.py, 22 March 2015) <http://www.zvuki.ru/R/P/35124/> accessed 29 March 2018.

46 Дарья Луганская, 'Минкомсвязи выступило против идеи Михалкова о налоге на интернет' [Darya Luganskaya, 'Ministry of Communications opposed the Mikhalkov's idea about the internet tax'] (PБK, 4 December 2014) <https://www.rbc.ru/technology_and_media/04/12/2014/54805928cbb20ff0f85ac556> accessed 29 March 2018.

47 Анастасия Голицына, 'МЭР раскритиковало идею антипиратского сбора в рунете' [Anastasiya Golitsyna, 'Ministry of Economic Development criticised the idea of the antipiracy levy for the Runet'] (Vedomosti, 24 November 2014) <http://www.vedomosti.ru/technology/articles/2014/11/24/mer-raskritikovalo-ideyuantipiratskogo-sbora-v-runete> accessed 29 March 2018.

48 ‘ФАС выступила против идеи введения «антипиратского» сбора' ['Federal Antimonopoly Service opposed the idea of introduction of the "antipiracy" levy'] (PБK, 11 December 2014) <https://www.rbc.ru/rbcfreenews/548993572ae596e6880f6414> accessed 29 March 2018.

49 Анастасия Голицына, 'Интернет-компании объяснили Путину вред от антипиратского сбора' [Anastasiya Golitsyna, 'Internet companies explained to Putin the harm of the antipiracy levy'] (Vedomosti, 1 December 2014) <https://www.vedomosti.ru/business/articles/2014/12/01/internet-kompanii-i-pravoobladateli-vystupili-protivnaloga> accessed 29 March 2018. 
and (4) internet search providers generally profit from illegal content because users use their services to locate illegal content and watch ads in the process.

The implementation of global licenses could, therefore, benefit numerous stakeholders as the licences would simplify the interaction with right holders and decrease the burden currently placed on courts and the government. The advocates of the global license scheme presented it as a silver bullet which would improve the position of right holders as their revenues would increase together with the use of their works and, at the same time, provide internet users with access to more content for less. Those in support of global licenses also maintained that content publishers would compete not by speculative trading of content but by improving their services, and internet search providers would get more search requests and revenue from advertising.

Overall, global licences were put forward as a better solution than conventional antipiracy legislation which tends focus on restriction of access to infringing content available online instead of provision of remuneration to right holders. According to the supporters of the global license proposal, it would allow for internet users to pay less for access to content and for right holders to receive more remuneration than they currently do. ${ }^{5051}$

\subsection{Arguments against global licenses}

Those opposing global licenses were concerned about the fact that these licenses were not to cover all creative works, and that they extended collective rights management without express permission of right holders - this being in direct contradiction with Russia's WTO obligations. ${ }^{52}$

In their opinion, such extended collective rights management infringed the rights of authors and right holders, and deprived them of the right to freely monetise their works. Moreover, they

\footnotetext{
${ }^{50}$ Матвей Алексеев, Светлана Поворазнюк, “Мы ни у кого ничего не хотим отбирать» Никита Михалков и Сергей Федотов о глобальной лицензии в интернете' [Matvey Alexeev, Svetlana Povoraznyuk, '”We do not want to take anything from anyone" Nikita Mikhalkov and Sergey Fedotov on global license on the internet'] (Lenta.ru, 6 April 2015) <https://lenta.ru/articles/2015/04/06/mikhalkovfedotov/> accessed 28 October 2018.

${ }^{51}$ It should be noted that a study conducted by IViR suggests that alternative remuneration systems (such as the global license) may be well-received by consumers and may also have certain positive effects compared with the traditional copyright model (see the next section of this paper).

52 When joining the WTO the Russia's representative promised to review the legal framework and eliminate noncontractual management of rights by 2014, which did not happen, see Report of the Working Party on the Accession of the Russian Federation to the World Trade Organization (WT/ACC/RUS/70/Add.1 WT/MIN(11)/2/Add.1), 1218.
} 
saw the designation of only one collective rights management organisation to administer the global license scheme to be a concern as it might cause antitrust issues and because such organisations are generally often perceived as lacking transparency. ${ }^{53}$ Indeed, the (now former) head of the Russian Authors' Society which supported the global license proposal has been found guilty of fraud in connection with his management of the organisation's property. ${ }^{54}$

Moreover, opponents argued that internet access providers would not be able to use their resources to grow their networks and offer internet access services to new users. Instead, global licenses will impose an economic burden on them: internet access providers would need to incur great expenses to develop currently non-existent equipment to analyse the online use of creative works, and to acquire more data storage capacity to store information about such use.

A major concern was the technical impossibility of monitoring and assessing the number of uses of creative works and, as a consequence, the inability to fairly distribute accumulated funds among right holders.

In 2015, Giprosvyaz, the institute for design of structures for communications affiliated with Rostelecom, a major Russian telecommunications service provider, conducted a study on the technical viability of implementing the global license proposal. ${ }^{55}$ Giprosvyaz concluded that, at the time of the study, there was no widely available technology which would allow the monitoring and analysis of internet traffic of the kind envisaged by the global license proposal. ${ }^{56}$ In addition, the task of monitoring the use of creative works by internet users would be rendered more difficult due to: (1) growing use of HTTPS and other encrypted protocols (in 2015 encrypted traffic amounted to $10-15 \%$ of the total traffic and was expected to increase to $30 \%$ by 2017 ), ${ }^{57}$ (2) use

\footnotetext{
53 Анастасия Голицына, 'Продюсеры требуют реформы обществ по коллективному управлению правами' [Anastasiya Golitsyna, 'Producers demand reform of the collective rights management societies'] (Vedomosti, 26 November 2015) <https://www.vedomosti.ru/technology/articles/2015/11/26/618522-prodyuseri> accessed 29 March 2018.

54 Маргарита Алехина, 'Экс-глава РАО получил 1,5 года колонии за мошенничество с недвижимостью' [Margarita Alyokhina, 'Ex-head of Russian Authors' Society was sentenced to 1.5 years of imprisonment for assets fraud'] (РБK, 19 June 2017) <https://www.rbc.ru/society/19/06/2017/5946db3c9a7947c2a318d621> accessed 29 March 2018.

55 ОАО «ГИПРОСВЯЗЬ», ‘ЗАКЛЮЧЕНИЕ о возможности технической реализации Концепции глобального лицензирования на сетях операторов связи' [JSC “GIPROSVYAZ”, 'REPORT on the possibility of technical implementation of the Concept of global licensing on networks of telecom operators'] <http://www.slideshare.net/temychk/ss-45304834> accessed on 29 March 2018.

56 ibid, 42.

57 ibid, 38
} 
of peer-to-peer protocols, such as BitTorrent (peer-to-peer traffic amounting to $15 \%$ of the total traffic), ${ }^{58}$ and (3) use of security and anonymity software and technology, such as Tor or VPN, which do not permit to distinguish repeated downloads of the same work and, as a consequence, can be used to artificially increase the number of downloads. ${ }^{59}$ Accordingly, Giprosvyaz estimated that the effectiveness of calculating online use of creative works in 2015 would not exceed $70 \%$, with a further potential decrease to $50 \%$ by $2017-2018 .^{60}$

At the same time, even if the available monitoring equipment was to be used, the cost of its purchase, installation, and maintenance would be prohibitively high. The Ministry of Communications estimated that all funds accumulated within the first 10 years from the implementation of the global license scheme would have to be spent to compensate the cost of purchase of such monitoring equipment. ${ }^{61}$

Some commentators also criticised the scheme by pointing out that it would infringe a number of users' rights. To increase the effectiveness of monitoring, it would be necessary to use more intrusive monitoring techniques, ${ }^{62}$ which could infringe users' rights to protection of private life. Moreover, the duty imposed on internet access providers to share user data with the ACRMO would infringe privacy of communication.

Users' inability to refuse accepting global licenses might also infringe their freedom to contract, and create implications under consumer protection legislation. Many users could also find themselves liable to pay the global license fees twice or even multiple times as such licenses were not to be granted per internet user but, instead, per every internet access services agreement a person has entered into. After all, one person can have more than one internet access agreement:

\footnotetext{
58 ibid, 39.

59 ibid, 20.

60 ibid, 39.

61 Дарья Луганская, 'Минсвязи предсказало банкротство кинотеатров при введении сбора Михалкова' [Darya Luganskaya, 'Ministry of Communications predicted bankruptcy of cinemas after introduction of the Mikhalkov levy'] $\quad(P 5 K, \quad 25 \quad$ December 2014$)$ <https://www.rbc.ru/technology_and_media/25/12/2014/549be1079a79474181277281> accessed 29 March 2018.

${ }^{62}$ For example, Systematika, the organisation requested by the Ministry of Culture to design conceptual technical implementation of the monitoring of the use of works, proposed that special monitoring software should be installed on users' computers, see Никита Лихачев 'Для реализации антипиратского сбора Михалкова предложили снимать копию трафика пользователей и ставить им «жучки»' [Nikita Likhachev, 'Copying of user traffic and "bugging" were proposed for implementation of Mikhalkov's antipiracy levy'] (TJ, 20 February 2015) <https://tjournal.ru/54143-mikhalkov-traffic-copy-agents> accessed 29 March 2018.
} 
for example, one covering internet access via his/her smartphone, and another to provide broadband connection for his/her home personal computer.

Finally, some critics have also pointed out that the global license concept was based on a false assumption that all online use of content is infringing. They pointed out that the proposal disregarded the fact that a significant part of creative works used online is used with permission of right holders, under licences (including open licenses), or because the works have entered the public domain. Use of creative works online can also fall under one of the available copyright exceptions, in particular under the private use exception which already, indirectly, requires internet users to pay a levy.

Amidst the heated discussions between the advocates and critics of the scheme, in June 2015, the Russian media have reported that the global license initiative has been removed from the list of issues monitored by the President's administration. ${ }^{63}$ Whilst the withdrawal of the President's support did not formally preclude the Ministry of Culture from continuing its work on the proposal, it has, arguably, led to the abandonment of the global license scheme.

Similarly, in the EU the Court of Justice of the European Union already addressed some of these concerns directly on some systems which appear to be very similar to the ones that would be needed in order to implement the global license system. In Promusicae ${ }^{64}$ underlined how national authorities and courts have to strike a fair balance between the protection of copyright and the protection of the fundamental rights of individuals who these measures affect. In Scarlet ${ }^{65}$, the CJEU ruled that the suggested filtering system was disproportionate and collided with Art. 15 of the E-commerce Directive, and later in Netlog ${ }^{66}$, expanding on similar reasoning added that these general filtering system challenged several fundamental rights protected under the Charter of Fundamental Rights of the European Union, including the ISP's freedom to conduct their business, users' right to the protection of their personal data and would put at risk the freedom of information. ${ }^{67}$

${ }^{63}$ Анастасия Голицына, 'Путин не поддержал идею авторского сбора в интернете' [Anastasiya Golitsyna, 'Putin did not support the idea of copyright levy on the internet'] (Vedomosti, 24 June 2015) <https://www.vedomosti.ru/technology/articles/2015/06/24/597866-putin-ne-podderzhal-ideyu-avtorskogo-sbora-vinternete> accessed 29 March 2018.

${ }^{64}$ C-275/06 Promusicae v Telefonica de Espana SAU.

${ }^{65}$ C-70/10 Scarlet Extended SA v Société belge des auteurs, compositeurs et éditeurs SCRL.

${ }^{66}$ C-360/10 Belgische Vereniging van Auteurs, Componisten en Uitgevers CVBA (SABAM) v Netlog NV.

${ }^{67}$ For further analysis of these cases see, for instance, Teunissen, P. [2018], The balance puzzle: the ECJ's method of proportionality review for copyright injunctions, 40(9) E.I.P.R. 579-593. 


\section{The last of a - very long - series of proposals}

Despite the controversies surrounding the proposal, the Russian global license was neither the first, nor will it be the last, proposal to address the ever-growing problem of online infringement via a collection of pre-existing tools available to copyright owners - namely (1) the collective management of the right of making available and (2) a remuneration system to address the harm caused by infringements of the reproduction right. These proposals have come in a number of different forms and names: alternative compensation system, content or kultur flat-rate, licence globale, artistic freedom voucher, non-commercial use levy, and sharing licence.

One of earliest proposal was Netanel's suggestion to allow users to share files and compensating copyright owners with a levy on products and services benefitting from filesharing, ${ }^{68}$ followed by Ku's suggestion of introducing a levy on internet service subscriptions. ${ }^{69}$ Others, like Gervais, suggested modifying existing collective licensing to extend it to filesharing, ${ }^{70}$ subjecting the making available right to mandatory collective management. ${ }^{71}$ Aigrain included the application of extended collective licence schemes in the different possible legal solutions to unauthorised file-sharing, ${ }^{72}$ Fisher, in his administrative compensation system, suggested replacing copyright law with a voluntary licence and a 'tax', ${ }^{73}$ Lessig proposed the temporary introduction of a similar system until licensed streaming replaced file-sharing. ${ }^{74}$ Litman

${ }^{68}$ N.W. Netanel, 'Impose a non-commercial use levy to allow free P2P file sharing', (2003) 17 J.O.L.T. 1.

${ }^{69} \mathrm{Ku}$, R.S.R. [2002], 'The creative destruction of copyright: Napster and the new economics of digital technology', [2002] 69 University of Chicago L.Rev. 263, 311-315; Ku, R.S.R. [2003], 'Consumers and creative destruction: fair use beyond market failure', 18 B.T.L.J. 539, 566.

${ }^{70}$ Gervais, D.J. [2005], 'The price of social norms: towards a licensing regime for file-sharing', 12 J.I.P.L. 39.

${ }^{71}$ This solution would keep the exclusive author's right in place and only limit the exercise of this right. Grassmuck, V. [2009] 'The World is Going Flat(-Rate)' (IP Watch, 11 May 2009, <https://www.ip-watch.org/2009/05/11/theworld-is-going-flat-rate/> and Guibault, L. and others, The future of levies in a digital environment: final report (Amsterdam: Institute for Information Law, 2003), 26-27

${ }^{72}$ Aigrain, P. [2008], 'Internet \& création-Comment reconnaître des echanges sur l'internet en finançant la creation? Inlibroveritas. NEXA, the Centre for Internet \& Society at the Polytechnic of Torino, shared Aigrain's view. See NEXA [2009], 'Position paper on file-sharing and extended collective licensing. nexa.polito.it/licenzecollettive. [12/08/2010].

${ }^{73}$ W.W Fisher, Promises to keep: technology, law and the future of entertainment, 2004 Stanford University Press.

${ }^{74}$ Lessing agrees with Fisher's proposal, but he anticipate the system would only serve for the interim. Lessig, L. [2004], Free culture: how big media uses technology and the law to lock down culture and control creativity, (Penguin Press, 2004. 300-04. He argued that file-sharing should be should be addressed with a system of compulsory licenses 
suggested that copyright owners should choose between authorising the 'sharing' of their works and being compensated by a blanket fee or levy/tax; and 'hoarding' their works in exclusively exploited, online ventures, DRM-secured. ${ }^{75}$ Lincoff proposed the creation of an 'online transmission right for musical works and sound recordings,,${ }^{76}$ which would combine the rights of reproduction, performance, and distribution. The Songwriters Association of Canada suggested introducing a right covering the sharing of music using any technology: the right to share ' $a$ copy of a copyrighted musical work without motive of financial gain' ${ }^{77}$ Dimita suggested the introduction and global implementation of a reasonable and unobtrusive remuneration right to cover for the unauthorised online dissemination of protected works: a 'positive' remuneration right for authors and copyright owners, centrally and collectively administered, which would compress and specify the condition under which the communication to the public and the reproduction rights might be exercised. ${ }^{78}$ Until 2013 Grassmuck collected all these proposals advanced by academics, industry experts, consumer and user organisations, collecting societies and political parties. On his website - the 'sharing licenses library'- he notes that they are 'as old as P2P file-sharing itself'. ${ }^{79}$

A multidisciplinary study of alternative remuneration systems conducted by IViR, University of Amsterdam's Institute for Information Law, ${ }^{80}$ revealed that alternative remuneration systems may be well-received by consumers as they are willing to experiment with alternative modes of access and compensation. In addition to that, such systems may also allow to tackle concentration of market power and licensing issues which are characteristic for traditional copyright model. ${ }^{81}$

similar to the one for cable retransmission, the fee being set by the governments striking the right balance. Ibid. 25455 .

${ }^{75}$ Litman, J. [2004], Sharing and stealing, 27(1) Hastings Communications \&Entertainment Law Journal, 1-50.

76 Lincoff, B. [2002], Full, fair and feasible solution to the dilemma of online music licensing, www.bennettlincoff.com/music.pdf.

77 Songwriters Association of Canada [2009], 'Proposal for the monetization of the file-sharing of music'. www.songwriters.ca/studio/proposal.php. [01/12/2009-No longer available].

78 G. Dimita, Copyright and Shared Networking Technologies 2010 https://qmro.qmul.ac.uk/jspui/handle/123456789/1303

${ }^{79} \mathrm{http}: / / \mathrm{www} . v g r a s s . d e / ? \mathrm{p}=1048$. For a more updated list see http://acs-companion.tumblr.com/lit.

${ }^{80}$ Quintais, J.P., Copyright in an Age of Access: Alternatives to Copyright Enforcement (Kluwer Law International, 2017). See <https://www.ivir.nl/projects/copyright-in-an-age-of-access-alternatives-to-copyright-enforcement/> accessed 12 April 2018.

${ }^{81}$ IViR, 'International Symposium on Alternative Compensation Systems for Digital Copyright' (IViR, 11 July 2015) <https://www.ivir.nl/international-symposium-on-alternative-compensation-systems/> accessed 12 April 2018. 


\subsection{The French Licence Globale}

The most famous of the alternative remuneration proposals - and the only precedent to the Russian proposal when it comes to parliamentarian discussion - was the French 'licence globale' of 2005 which, similarly to its Russian equivalent, sparked a heated debate and was eventually abandoned. The proposal envisaged the adoption of a remuneration system for peer-to-peer global file-sharing on the basis of a mandatory contractual licence combined with a statutory licence, and administered by a mandatory collective administration, a 'global licence'. ${ }^{82}$ The French proposal was deeply studied by academics worldwide and, importantly, was deemed feasible by one of the most extensive studies on the topic which also deemed it to be in conformity with international treaties. ${ }^{83}$ The study concluded that, adapting the existing system of remuneration, downloading could be covered by the private copying exception, and further suggested a mandatory collective management for the 'making available' right. It also emphasised the efficiency of the precedent collective managements for reprography and cable broadcast. ${ }^{84}$ Of the opposite view was the International Literary and Artistic Association, ALAI, which, with a resolution adopted in 2006, ${ }^{85}$ condemned it as being in conflict with international treaties.

The proposal was promoted by the Alliance Public-Artistes, ${ }^{86}$ and was supported by politicians from very different backgrounds. The Alliance Public-Artistes commissioned two

${ }^{82}$ Mazziotti, G., EU Digital Copyright Law and the End-User (Springer Science \& Business Media, 2008) 261.

83 Bernault, C. and Lebois, A., 'Peer-to-peer File Sharing and Literary and Artistic Property' <http://privatkopie.net/files/Feasibility-Study-p2p-acs_Nantes.pdf> accessed 9 April 2018.

${ }^{84}$ Ibid. 48

${ }^{85}$ See L'Association Littéraire et Artistique Internationale at http://www.alai.org.

86 Alliance Public-Artistes, Campagne de sensibilisation au projet de loi DADVSI' <http://www.lalliance.org/pages/1_1.html> accessed 12 August 2010. 
studies on the feasibility of the model from a technical ${ }^{87}$ and economic ${ }^{88}$ perspective. The proposal implementing the licence globale was subsequently discussed ${ }^{89}$ but, ultimately, was not included in the final version of the French law on authors' rights and related rights in the information society, the so-called DAVDSI law. ${ }^{90}$ At the time, the Association Litteraire et Artistique Internationale issues a resolution warning for the 'utmost circumspection with regard to every proposal to replace copyright's primary basis in the private law model of an exclusive right by models based on statutory remunerations'. ${ }^{91}$

\subsection{The German Kultur Flat-rate}

Even though it never received parliamentary discussion, it is definitely worth adding to the analysis the levy-based file-sharing permission proposed by the German Green political party in their campaign for the 2009 European Parliament Elections. ${ }^{92}$ The German Social Democrats Political Party (SPD) followed the Green lead, introduced a similar proposal in their draft for the

87 BigChampagne Online Media Measurement, 'Monitoring and Identifying P2P Media' <http://alliance.bugiweb.com/usr/documents/etudespedidambigchampagne-en-janv2006.pdf> accessed 12 August 2010.

${ }^{88}$ Alliance Public-Artistes, 'PRESS KIT: Downloading and sharing files on the Internet, An alliance against legal proceedings, An alliance for a global licence' <http://www.alliance.bugiweb.com/usr/Documents/PressKitJune2005.pdf> accessed 12 August 2010.

89 Orlowski, A., 'France votes to legalize flat-fee P2P downloads' (The Register, 22 December 2005) <www.theregister.co.uk/2005/12/22/france_legal_p2p_flat_fee> accessed 12 April 2018.

90 The law was passed in 2006 to reform French copyright law, mostly in order to implement the European Copyright Directive (Directive 2001/29/EC). Loi $n^{\circ}$ 2006-961 du $1^{\text {er }}$ août 2006 relative au droit d'auteur et aux droits voisins dans la société de l'information.

91 RESOLUTION FOLLOWING THE 2015 BONN CONGRESS OF ALAI, Rome, 14 September 2016. http://www.alai.org/en/assets/files/resolutions/20160914-resolution-Bonn_en.pdf accessed 20 May 2015

${ }^{92}$ Europawahlprogramm (vorläufig, Stand: 31.01.09), Point VIII: Kultur, Bildung und Forschung-Der GRÜNE Weg in die Wissenschaftsgesellschaft, 29 Ordentliche Bundesdelegiertenkonferenz, Dortmund, 23-25 January 2009, <www.gruene-partei.de/cms/default/dokbin/267/267132.kapitel_viii_kultur_bildung_und_forschun.pdf> accessed 12 August 2010. 'Compensation for artistic contributions on the internet. We want to develop a fair process to compensate artists for the dissemination on the internet or elsewhere of their works. In the digital era, we need to strengthen the rights of consumers. We are committed to a differentiated solution that may include an all-inclusive fee for music, movies and other media and content. The introduction of a culture-flat-rate, which allows the use of digital cultural assets for non-commercial use, can be a solution for this. The revenue must come transparently and equitably in the first place to the authors' own benefit. We clearly reject the current massive wave of legal action, interference with privacy, the use of DRM or data traffic filters. They are a disproportionate interference with the users' rights. Translation by J.L.A. Himmrich, reproduced with consent. 
national election. ${ }^{93}$ According to the proposal, users would pay a flat rate for the right to share, and an online collecting society would pay authors and publishers according to the measured use of their works. The minimal requirement for such a solution should be: ${ }^{94}$

1. a licence permitting users to share protected works for non-commercial purposes;

2. a flat-rate levy, possibly collected by the internet access provider; and

3. a collective management system.

This approach would limit the possibility to enforce copyrights against users, but the copyright owners would be compensated in the form of an equitable remuneration. From an economic perspective, this could be argued to be an improvement over the current situation where copyright owners are not compensated for the unauthorised dissemination of their works over the internet. ${ }^{95}$ The German Green party also commissioned a study on the legal feasibility of this approach. ${ }^{96}$ The conclusion was positive and a number of scholars, ${ }^{97}$ representatives from the music industry, ${ }^{98}$ collecting societies' advisors, ${ }^{99}$ and activists ${ }^{100}$ supported the Kultur flat-rate considering it to be the only meaningful solution to the problem of illegal file-sharing.

\footnotetext{
${ }^{93}$ Entwurf des regierungsprogramms der SPD. Antrag des SPD-Parteivorstandes an den Bundersparteitag der SPDD am 14 June 2009, 48, 〈http://www.frankwaltersteinmeier.de/_media/pdf/Entwurf Regierungsprogramm.pdf $>$ accessed 12 August 2010. Fair remuneration for creative work. As part of the social democratic creative-package, we wants to ensure that cultural and media professionals, artists can live from their creative work. It depends on the intellectual property to protect and compensate them adequately. It is important to protect intellectual property and to remunerate it appropriately. Copyright and copyright contract law should allow a decent income from the exploitation of intellectual property in the digital environment. The future of digitization brings new challenges in the protection of intangible products and goods. We need a reasonable balance between usability and the rights of the creators. In the framework of the creative-package, we will involve network operators and internet service providers in a dialogue with rights holders and collecting societies. We are committed to the examination of a culture flat-rate'. Translation by J. Himmrich, reproduced with consent.

${ }^{94}$ Roßnagel, A., director of the 'Institut für Europäisches Medienrecht in Zusammenarbeit mit der Projektgruppe verfassungsverträgliche Technikgestaltung an der Universität Kassel' (hereinafter EML), cited in Grassmuck, V. [2009], op.cit.

${ }^{95}$ Grassmuck, V. [2009], op.cit.

96 EML [2009], 'Die Zulässigkeit einer Kulturflatrate nach nationalem und europäischem Recht', www.boersenblatt.net/sixcms/media.php/747/ kulturflatrate.pdf. [12/08/2010]

97 For instance, Hoeren (www.webseiten-infos.de/youtube-und-das-urheberrecht); Flechsig (blog.beck. de/2008/08/12/flechsig-und-die-flatrate); Wandtke (waste.informatik.hu-berlin.de/grassmuck/Texts/08-03_state-offlatrate.html); and Peukert (www.heise.de/newsticker/digital-rights-management-welche-alternativen-sind-rechtlichmoeglich/meldung/55150). [12/08/2010].

${ }^{98}$ For instance, Renner (www.merkur.de/2008_40_eine_loesung_is.30479.0.html?\&no_cache=1). [12/08/2010].

${ }^{99}$ For instance, Leonhard (www.mediafuturist.com/music_like_water). [12/08/2010].

${ }^{100}$ For instance, http://privatkopie.net and www.fairsharing.de. [12/08/2010].
} 


\section{Conformity with international obligations}

Most of the criticisms raised against these proposals focus on the lack of conformity with international treaties, the complexity in administering such systems, calculation of the levy, and privacy issues. However, the complexity of a system and/or calculation of a levy should not, of themselves, be used as an incontestable argument against a proposal. After all, any system of collective management is, by its nature, complex and imprecise - this has never been an obstacle to implementation. Similarly, as regards the levy calculation, there are systems already in place in every jurisdiction that allow to establish the optimal rate. The privacy concern is more important, but it could be easily solved by non-intrusive and anonymous monitoring - an accurate system requires the monitoring of the number of times a work has been shared and the volume of sharing per user. There is no need to connect the actual work with identified users - anonymization could easily address any privacy concern. This leaves us with the issue of conformity with international obligations.

Every proposal must conform to the obligations under Berne, TRIPs, WCT, and WPPT Treaties. In particular, it must comply with the three-steps-test by which (1) limitations on exclusive copyrights are confined to 'certain special cases' which (2) do not conflict with a 'normal exploitation of the work' and (3) do not 'unreasonably prejudice the legitimate interests of the author'. ${ }^{101}$ Most of the aforementioned proposals rarely deal with this aspect. ${ }^{102}$ Lessig acknowledges that 'some of the changes' he proposes would require amendments to, 'or the abrogation of some treaties'. ${ }^{103}$ Fisher admits that his proposed limitation to exclusive rights necessitates amendments to Berne and TRIPs. ${ }^{104}$ Litman herself doubts her proposal is three-step-

\footnotetext{
${ }^{101}$ Gervais, D.J. [2005], 'Towards a new core international copyright norm: the reverse three-step-test', 9 Marquette Intellectual Property L.Rev. 1, 33. Ginsburg, J.C. [2001], 'Toward supranational copyright law? The WTO panel decision and the 'three-step-test' for copyright exceptions', 187 R.I.D.A 3. Sirinelli, P. [1999], 'Exceptions and limits to copyright and neighbouring rights', Workshop on Implementation Issues of the WCT and the WPPT, WIPO Document WCT-WPPT/IMP/1 of 3 December 1999, 42. Peukert, A., 'A bipolar copyright system for the digital network environment', in Strowel, A., Peer-to-peer file sharing and secondary liability in copyright law (Edward Elgar, 2009) 148-176.

${ }^{102}$ Lunney, G.S. [2001], The death of copyright: digital technology, private copying, and the Digital Millennium Copyright Act', [2001] 87 Virginia L Rev, 813, 910-918; Sobel, L.S. [2003], Symposium: the law and economics of digital rights management: DRM as an enabler of business models: ISPs as digital retailers, 18 B.T.L.J. 667, 673; Ku, R.S.R. [2002], op.cit. 311-315; and [2003], op.cit. 566. Lemley, M.A. and Reese, R.A. [2004] 'Reducing Digital Copyright Infringement Without Restricting Innovation', 56 Stanford Law Review, 1345, 1414-31. The exception is Eckersley, who discussed in details Article 13 of TRIPS. Eckersley, P. [2004] 'Virtual markets for virtual goods: the mirror image of digital copyright?' 18 J.O.L.T. 85152-158.
}

${ }^{103}$ Lessig, L. [2004], op.cit., 251.

${ }^{104}$ Fisher proposed a new 17 U.S.C. §107A. Fisher, W.W. [2004], op.cit. 247. 
test compliant. ${ }^{105}$ Netanel merely states that his levy is TRIPs-compliant. ${ }^{106}$ The issue is not just theoretical ${ }^{107}$ - the German Ministry of Justice declined to introduce a new limitation for noncommercial file-sharing, explicitly referring to the three-step test. ${ }^{108}$ This does not mean that such treaties are not perfectible. However, the complexity of the procedure and the required consensus of all contracting parties for amendments makes any sort of modification to international treaties appear unrealistic. ${ }^{109}$ Therefore, a proposal drawing a limitation/exception to one of the exclusive rights - which are 'mandatory minimum rights in international copyright law' ${ }^{110}$ - has to be subject to the three-step test. ${ }^{111}$ This test, in its TRIPs version, states:

Members shall confine limitations or exceptions to exclusive rights to certain special cases which do not conflict with a normal exploitation of the work and do not unreasonably prejudice the legitimate interests of the right holder. ${ }^{112}$

These steps are considered cumulatively ${ }^{113}$ and successively. ${ }^{114}$

${ }^{105}$ Litman, J.C. [2004], Sharing and stealing, 27(1) Hastings Communications \&Entertainment Law Journal, 1-50, 39.

${ }^{106}$ Netanel, N.W. [2003], Impose a non commercial use levy to allow free P2P file sharing, 17 J.O.L.T. 1,. 60.

${ }^{107}$ Peukert, A. [2009], A bipolar copyright system for the digital network environment, in Strowel, A. [2009] Peer-topeer file sharing and secondary liability in copyright law, Edward Elgar, 148-176.

108 BMJV, Bill for a ' $2^{\text {nd }}$ Act on Copyright in the Information Society', 27 September 2004, 33-34. See <http://www.bmj.bund.de/files/630f712008607f2bf49cde66e5a84046/760/referentenentwurf urheberr.pdf > accessed 14 August 2010.

109 On the difficulties to amend the TRIPS Agreement, see Gervais, D.J. [2005], Towards a new core international copyright norm: the reverse three-step test', 9 Marquette I.P.L.Rev. 1 ('Far from simple politically'); Gervais, D.J. [2005], 'The price of social norms: towards a licensing regime for file-sharing', 12 J.I.P.L. 39. ('Any proposal to license P2P should take account of applicable international treaties'). Eckersley, P. [2004], Virtual markets for virtual goods: the mirror image of digital copyright? 18 J.O.L.T. 85, 157.

${ }^{110}$ Article 9 Berne, Article 9(1) TRIPS, agreed statement concerning Article 1(4) WCT; Articles 11, 11bis(1), 11ter(1), 14(1), 14bis(1) Berne, Article 8 WCT, Articles 10, 14 WPPT.

${ }^{111}$ Article 9(2) Berne and later in Article 13 TRIPS, Article 10 WCT and Article 16(2) WPPT. Ricketson, S. [2003], 'WIPO Study on Limitations and Exceptions of Copyright and Related Rights in the Digital Environment', WIPO publication SCCR/9/7.

112 Article 13.

${ }^{113}$ Failure to comply with any one of the three conditions results in the limitation/exception being disallowed. WTO Panel, Dispute DS160, §110(5) US Copyright Act, 7 January 2002, Para. 6.74, 6.97 Reinbothe, Jörg and von Lewinski, Silke, The WIPO treaties 1996 (Butterworths 2002), Article 10 WCT no. 14. Ricketson, S. [2003], WIPO study on limitations and exceptions of copyright and related rights in the digital environment, WIPO publication SCCR/9/7.

${ }^{114}$ Records of the WCT negotiations, reproduced in Ficsor, M. [2002], The law of copyright and the internet-The 1996 WIPO Treaties, their interpretation and implementation (OUP 2002) 71; and in Ginsburg, J.C. [2001], Toward supranational copyright law? The WTO panel decision and the "three-step test" for copyright exceptions', 187 R.I.D.A 3, 40. Moreover, the interpretation of the test must take into consideration the aim of the instruments which include it. This aim was to harmonise national laws in order to provide for adequate, balanced copyright protection. With 
Divergent opinions exist as to what this requirement means in detail. A restriction must be 'clearly defined and narrow in its scope'. ${ }^{115}$ The scope has to be 'known and particularised' so that it is foreseeable whether or not a given use will be subject to the limitation/exception. ${ }^{116}$ Moreover, the scope has to be 'narrow', both in a qualitative and in a quantitative sense. ${ }^{117}$ This can, however, be read in a number of alternative ways. For instance, it has been suggested that 'certain special cases' should relate to the legitimacy of the policy rationale rather than to the extent of the coverage of the exception. ${ }^{118}$ On the other hand, it seems clear that this condition does not rule out various other concepts, such as fair dealing or fair use - it is 'an incalculable, shapeless provision exempting a wide variety of different uses' that is deemed impermissible. ${ }^{119}$ Concerning the 'specialness' of the limitation or exception, various commentators question whether some clear reason of public policy, a rational basis for justification exists for the restriction, ${ }^{120}$ or whether users' interests need to be reconciled with the copyright owner's interests. ${ }^{121}$ The WTO Panel considered the public policy issue of subsidiary relevance in applying the first step. ${ }^{122}$ It could be argued, however, that a limitation/exception for private non-commercial uses is clearly defined

regard to Berne, Ficsor, M. [2002], op.cit. 5.06-8; regarding Article 7-8 TRIPS, WTO Panel, DS114 Canada-Patent Protection of Pharmaceutical Products, 18 August 2000, Para. 7.26; regarding the WCT, Ricketson, S. [2003], op.cit. Reinbothe-von Lewinski [2002], op.cit. Article 10 WCT.

${ }^{115}$ Ricketson, S. [2003], op.cit. WTO Panel, Dispute DS160, §110(5) US Copyright Act, 7 January 2002, Para. 6.112; Ficsor, M. [2002], op.cit. 129, 227; Reinbothe-von Lewinski, [2002], op.cit. Article 10 WCT, 15. With regard to Article 30 TRIPS ('limited exceptions'), WTO Panel, DS114 Canada-Patent Protection of Pharmaceutical Products, 18 August 2000, Para. 7.30. Ficsor, M. [2002], op.cit. 151 (extensive use of compulsory licensing not in line with Article 13 TRIPS).

${ }^{116}$ WTO Panel, Dispute DS160, §110(5) US Copyright Act, 7 January 2002, Para. 6.108; Senftleben, M., Copyright, Limitations and the Three-step test. An Analysis of the Three-Step Test in International and EC Copyright Law (Kluwer Law International, 2004)137.

117 Ibid.

${ }^{118}$ See, for instance, Griffiths, J. [2010], Rhetoric \& the 'three-step-test': copyright reforms in the United Kingdom, 32(7) E.I.P.R. 309-312. Ficsor, M. [2002], How Much of What? R.I.D.A. 111, Senftleben, [2004], Copyright, limitations and the three step test: an analysis of the three step test in the international and EC copyright Law, Kluwer Law International, 144-152; He, H. [2009], Seeking a Balanced Interpretation of the Three-Step Test: an Adjusted Structure in View of Divergent Approaches I.I.C. 274.

${ }^{119}$ Senftleben, M. [2004], op.cit. 133-137. Ricketson, S. [2003], op.cit. Gervais argues that only the second and third step really embody a restriction to future limitations and exceptions, because few countries would act in a purely arbitrary way introducing exceptions that imply a complete repeal of copyright law. Gervais, D.J. [2005], op.cit. 17.

${ }^{120}$ Ricketson, S. [2003], op.cit. Ficsor, M. [2002], op.cit. 129-32. Reinbothe-von Lewinski, [2002], op.cit. Article 10 WCT no. 15.

${ }^{121}$ Senftleben, M. [2004], op.cit. 144-152. Ricketson, S. [2003], op.cit.

122 WTO Panel, Dispute DS160, §110(5) US Copyright Act, 7 January 2002, Para. 6.102-13; Ginsburg, J.C. [2001], 'Toward supranational copyright law? The WTO panel decision and the "three-step test' for copyright exceptions', 187 R.I.D.A 339-43. 
and narrow in scope and can easily be distinguished from non-permitted uses. ${ }^{123}$ Consequently, it could, theoretically, constitute a 'certain special case'. ${ }^{124}$

'Normal exploitation' refers to what a copyright owner may expect from present or future (potential) markets. ${ }^{125}$ However, this is open to contrasting interpretations. For instance, with the increasing availability of ways to exercise economic rights, the range of 'normal' exploitations increases with the consequent decrease of the margins for the introduction, or even maintenance, of limitations and exceptions. Therefore, when defining the second step, it should be accepted that a 'conflict' should arise only when the exception 'substantially impair[s] ... the overall commercialisation of that work by divesting the authors of a major source of income'; ${ }^{126}$ and that 'normal' exploitation is not the full use of an exclusive right. Otherwise, every restriction would be impermissible, and thus the provision itself superfluous. 'Normal' implies an empirical and a normative element. ${ }^{127}$ Regarding the degree of market displacement following from the restriction, different standards have been articulated. It has been maintained that a limitation/exception conflicts with normal exploitation if: ${ }^{128}$

- it causes a serious loss of profit;

- it covers uses for which the author would ordinarily expect to receive a fee;

- it applies to those forms of exploitation that currently generate significant or tangible revenue or which, with a certain degree of likelihood and plausibility, could acquire considerable economic or practical importance as opposed to uses that do not compete with non-exempted uses (actual and potential effects).

On this point, a passage from Grokster is interesting:

one striking example provided by the software distributors is the popular band Wilco, whose record company had declined to release one of its albums on the basis

\footnotetext{
${ }^{123}$ Peukert, A. [2009], op.cit. 163-4; Lessig, L. [2004], op.cit. 296-7. Senftleben, M. [2004], op.cit. 140-4, 162.

124 EML [2009], 'Die Zulässigkeit einer Kulturflatrate nach nationalem und europäischem Recht', www.boersenblatt.net/sixcms/media.php/747/ kulturflatrate.pdf. 27.

${ }^{125}$ Mazziotti, G. [2008], op.cit. 83.

126 Senftleben, M. [2004], op.cit. 193.

${ }^{127}$ Peukert, A. [2009], op.cit. 165.

128 Ibid.
} 
that it had no commercial potential. Wilco repurchased the work from the record company and made the album available for free downloading, both from its own website and through the software user networks. The result sparked widespread interest and, as a result, Wilco received another recording contract. ${ }^{129}$

Thus, experience shows that 'normal exploitation' is not eliminated if the work had already been available on networks. As has been highlighted, the second-step analysis would be better if complemented by 'market research to draw concrete conclusions'. ${ }^{130}$ Nevertheless, it is submitted that 'normal exploitation' should not refer to a particular business model. Thus, if a new alternative method of exploitation, differently compensated, became 'normal', the limitation that allows it might then be argued to comply with the second step. ${ }^{131}$

Lately, the question was raised of whether non-economic considerations should be taken into account, in particular, the public interest. In fact, a pure economic approach would too often paralyse any application of limitation and exception in the digital environment. ${ }^{132}$ This reading appears to break radically with the traditional interpretation of the second step, and would practically diminish the importance of the third step. ${ }^{133}$ However, the authors of this paper are of the view that user initiated dissemination of information is a democratic necessity that needs to be balanced with the rights of the authors and other copyright owners. ${ }^{134}$

The third step requires limitations to be 'justifiable' and 'reasonably' supported by public policies or other social needs. ${ }^{135}$ The crucial questions are therefore concerned with whether the interests at stake are legitimate, and at which point the level of 'prejudice' may become

\footnotetext{
${ }^{129}$ MGM Studios, Inc. v. Grokster Ltd., 380 F.3d 1154, 1161 (9th Cir. 2004). The Supreme Court did not refer to this example expressly but stated that 'some musical performers [...] have gained new audiences by distributing their copyrighted works for free across peer-to-peer networks [...]'. MGM Studios, Inc. v. Grokster Ltd. 125 S.Ct. 2764, 2772 (2005).

${ }^{130}$ Grassmuck, V. [2009] op.cit.

${ }^{131}$ EML [2009], op.cit.

${ }^{132}$ Ginsburg, J.C. [2001], op.cit. 48-52; Senftleben, M. [2004], op.cit. fn.9, 181

${ }^{133}$ Lucas, A. [2010], For a reasonable interpretation of the three-step test, 32(6) E.I.P.R., 277-282.

${ }^{134}$ See, in this sense, Netanel, N.W. [1996], op.cit.; Senftleben, [2004], op.cit. 33-34.

${ }^{135}$ WTO Panel, Dispute DS160, §110(5) US Copyright Act, 7 January 2002, Para. 7.69; Gervais, D.J. [2005], op.cit. 19-20.
} 
'unreasonable'. ${ }^{136}$ Nevertheless, the introduction of a levy-based compensation system appears to respond to this requirement. ${ }^{137}$ In a sense, a remuneration system rebalances the prejudice making 'reasonable' what would otherwise be 'unreasonable', if left uncompensated: ${ }^{138}$

The interests of authors and exploiters of the third step have to be weighed against the interests of the general public and against possible alternatives. Assuming an appropriate remuneration [...] the prejudice would not be unreasonable. ${ }^{139}$

The above analysis is controversial, and some commentators disagree with such conclusions. ${ }^{140}$ The reason for this negative assessment is that all international conventions rest upon the perception that copyright is a private, exclusive right. Accordingly, non-voluntary licenses are the exception to this rule, and they have to be of a limited nature. ${ }^{141}$ Moreover, there is a tendency to overlook the fact that the three-step test was introduced as a diplomatic agreement with relatively loose constraint, permitting parties of the Berne Convention to retain their existing limitations and exceptions, and avoid a disharmonised evolution of national limitations and

136 Senftleben, M. [2004], op.cit. 226-241. Ricketson, S. [2003], op.cit. Reinbothe-von Lewinski, [2002], op.cit. Article 10 WCT no. 23. Ginsburg, J.C. [2001], op.cit. 53. Peukert, A. [2009], op.cit. 172. German Federal Supreme Court, Gewerblicher Rechtsschutz und Urheberrecht (GRUR) 963, 967 (2002).

${ }^{137}$ Senftleben, M. [2004], op.cit. 237.

${ }^{138}$ Dusollier-Ker [2009], 'Private copy levies and technical protection of copyright: the uneasy accommodation of two conflicting logics, in Estelle Derclaye (edn), Research handbook on the future of EU copyright, (EE 2009), 349$372,353$.

${ }^{139}$ EML [2009], op.cit. 28.

140 Rietjens, B. [2006], 'Copyright and the three-step-test: are broadband levies too good to be true?' 20(3) International Review of Law Computer \& Technology 323-336. 'Indeed, an exception for large-scale 'private' copying of the 'sharing' type might well conflict with a normal exploitation'. Ginsburg, J.C. [2001], op.cit.55-6. 'Placing of an entire protected work on the digital networks for free access may unreasonably prejudice the author's interests in a considerable degree' Reinbothe-von Lewinski [2002], op.cit. Article 10 WCT no. 22. 'It is difficult to see any justification that can be made for these uses under the three-step-test'. Ricketson, S. [2003], op.cit. 80. '[the three-step-test] might just prove itself flexible enough to allow some limited experimentation with virtual markets [although it] was devised as a mechanism to reinforce a model of copyright based in exclusive rights. Eckersley, P. [2004] 158.

${ }^{141}$ A broad levy system has not generally been accepted as a true alternative to exclusive rights in the history of international copyright law. A general compulsory license for the dissemination of knowledge was rejected in 1967, during the Stockholm Conference. Report in Ricketson, S. [2003], op.cit. 481. Germany suggested that exceptions to the reproduction should not conflict with the author's right to obtain equitable remuneration. Ibid. 196. Remuneration schemes for private copying were discussed prior to the WIPO conference in 1996, but they were not included in the conference's agenda. This holds true also for the WIPO Treaties of 1996. Various statements at the WIPO Symposiums in 1993, 1994, and 1995 stressed the notion of copyright as an exclusive right in cyberspace. Ficsor, M [2002], The law of copyright and the internet-The 1996 WIPO Treaties, their interpretation and implementation (OUP 2002) 5.125-7, 5.113-120, C10.33. 'It would be preferable to admit private copying as an enforceable right against technical devices and to solve the problem by a working system of equitable remuneration'. Geiger, C. [2005], Right to copy v. three-step test, 1 C.R.I. 7, Para. 371-380. 
exceptions. The interpretation of the test should therefore be flexible and balanced. Restrictive interpretations appear to be unjustified when they contrast with the test's original ratio.

Nevertheless, the test itself produces a number of problems in an era in which legislative freedom and broad harmonisation are needed. In particular, it has been noted that:

Organisations representing right-holders now frequently suggest that expansions to the scope of exceptions in copyright law would, or might, be incompatible with the 'three-step test' and would therefore contravene international and European law. [...] Given the fundamentally uncertain requirements of the 'three-step test' and taking into account the role it was originally designed to fulfil, these claims are usually little more than misleading wishful-thinking. ${ }^{142}$

Thus, the test has come under pressure owing to its rigidness and restrictive approach, as well as its inability to allocate the balance between the interests involved. An international consensus regarding the scope of the test is still missing, and it has been suggested that the test may block the limitations adjustments needed, in particular, for networking technologies. ${ }^{143}$ The serious risk is that:

the three-step test will further constrain the existing architecture of copyright, will limit both judicial and legislative freedom, and incrementally suppress and subdue balances that exist in national systems. ${ }^{144}$

Nevertheless, the three-step-test is probably not the true reason why these proposals keep failing.

\section{Conclusion}

The digital environment, undoubtedly, still poses challenges to the current copyright regime thus forcing us to keep overthinking the existing system. This is why we believe proposal

\footnotetext{
${ }^{142}$ Griffiths, J. [2010], Rhetoric \& the 'three-step test': copyright reforms in the United Kingdom, 32(7) E.I.P.R. 309312. 309.

${ }^{143}$ Westkamp, G. [2008], 'The three-step-test and copyright limitations in Europe: European copyright law between approximation and national decision making', J.C.S.U.S.A. 2-3, 11, 31-32. Max Planck-Queen Mary [2009], 'Declaration: a balanced interpretation of the three-step-test', www.ip.mpg.de/ shared/data/pdf/declaration_three_steps.pdf. [13/08/2010]. Geiger, C. [2009] op.cit. 627-37.

${ }^{144}$ Westkamp, G. [2008], op.cit. 63.
} 
for alternative compensation or remunerations system keep reappearing notwithstanding the heated opposition.

The main opposition to alternative remuneration systems is the accusation that it is an expropriation of the copyright owners' exclusive 'property' rights. ${ }^{145}$ However, 'the protection of property does not mean an absolute guarantee of preservation of the status quo, in the sense that all achieved legal positions are sacrosanct'. ${ }^{146}$ Promoters of alternative remuneration systems argue that it is rather a limitation of rights in conformity to the principle of proportionality, not an expropriation. These proposals serve legitimate purposes; they are adequate, necessary and appropriate; ${ }^{147}$ they resolve the collision of rights between copyright owners and users, ensuring remuneration and respecting the privacy of users. These proposed systems are not only legitimate but also necessary given the large numbers of infringements - and infringers - preventing copyright owners from enforcing their rights. ${ }^{148}$ They are also, arguably, adequate and proportionate. $^{149}$

Another criticism of alternative remuneration systems is the argument that those users who do not infringe copyright would be required to pay a levy anyway. ${ }^{150}$ This, however, could be mitigated by calculating the sums users are required to pay in proportion to their bandwidth

\footnotetext{
${ }^{145}$ For example, among the 'Ten arguments against the kultur flat-rate' the Association of German Music Industry argud that: ' 6 ) the culture flat-rate takes away from creators and artists the right to control the usage of their works; 7) the culture flat-rate is inconsistent with the economic principles of our society; [... 9) the culture flat-rate devalues intellectual property. Bundesverband Musikindustrie [2010], Bundesverband Musikindustrie veröffentlicht $\begin{array}{llll}\text { Positionspapier } & \text { zur } & \text { Kulturflatrate, } & 25 \\ \end{array}$ 〈www.musikindustrie.de/fileadmin/news/presse/100125_Kulturflatrate_10_Argumente_FINAL.pdf >. Translated in Dobusch, L. [2010], Extending private copying levies: approaching a culture flat-rate?, <http://governancexborders.wordpress.com/2010/01/30/extending-private-copying-levies-approaching-a-cultureflat-rate> accessed 15 August 2010.

${ }^{146}$ EML [2009], op.cit. 14.

${ }^{147}$ Grassmuck, V. [2009], op.cit.

${ }^{148}$ EML [2009], op.cit. Conclusions. 'Copyrights in contradistinction to material property are in the final instance not intended to exclude others from the use of works but to enable authors to generate earnings from their exploitation'. Ibid.

149 Ibid.

150 This is not unprecedented: the introduction of private coping levies and the public broadcast fee caused similar critiques. Moreover, in a sense, notwithstanding the differences between remunerations systems, levies and taxes, citizens often pays for services they do not use. For instance, taxes paid by healthy people without children are often used to finance health care and schools.
} 
consumption. ${ }^{151}$ Sharing a protected work over a network consumes substantial bandwidth and if, as it has been claimed, ${ }^{152}$ there is a direct connection between high-speed broadband and widespread copyright infringement, then 'a graduated levy would be a fair solution'. ${ }^{153}$

Even then, the true reason these proposals keep failing appears to be, arguably, the resistance and conservativeness of some of the stakeholders: copyright owners do not want to lose control, ISPs do not want to see their costs increase - hence the preference on maintaining and reinstating old business models. However:

When a business model has become dated due to changed technological or social circumstances it would even be inadmissible to protect and artificially keep it alive through massive law-making intervention. ${ }^{154}$

Finally, it should be noted, in support of these proposals that, if implemented, they would reduce the number of entities draining from the copyright value chain (credit card companies, iTunes, host providers, streaming service providers, etc.). Already in 2008 the 'Attali Commission', ${ }^{155}$ in its report on policies to overcome economic growth's restrictions, ${ }^{156}$ presented a levy on internet use 'as a reconciliation of economic development and free legal downloading'. ${ }^{157}$ The report also suggested that filtering and monitoring systems conflict with constitutional rights and fundamentally undermine economic growth and, subsequently, it concluded that a levy on internet access providers would ensure a fair compensation for authors and other copyright owners without penalising internet development. ${ }^{158}$

Copyright reforms should be addressed in line with the 'bigger picture' of the impact of these reforms on society as a whole. For instance, in 2012, the Council of Europe passed a

\footnotetext{
${ }^{151}$ In University campuses, for instance, they have been calculated to consume $75 \%$ of the total capacity. Wade, J. [2004], The music industry war on piracy, 51(2) Risk Management, 10-15.

152 Para. 2.4.2.

153 Aigraain, P. [2008], op.cit.

${ }^{154}$ Grassmuck, V. [2009] op.cit.

${ }^{155}$ A commission set up by President Sarkozy following his election in 2007 to improve the level of competitiveness of the French economy.

156 Attali, J. [2008], Rapport de la Commission pour la libération de la croissance française, <www.liberationdelacroissance.fr/files/rapports/RapportCLCF.pdf> accessed 15 August 2010.

${ }^{157}$ Ibid. Objective leading to Action 57.

${ }^{158}$ Ibid. Decision on Action 57.
} 
comprehensive 'Internet Governance Strategy' setting the main action lines of the strategy that would govern its internet-related work as: ${ }^{159}$

- maximising rights and freedoms for internet users;

- advancing data protection and privacy;

- enhancing the rule of law and effective co-operation against cybercrime;

- maximising the internet's potential to promote democracy and cultural diversity;

- protecting and empowering children and young people.

Unfortunately, notwithstanding the fact that global license proposals perfectly align with the above aims, they are still not receiving the deserved attention.

A new regime is probably necessary in order to guarantee copyright holders remuneration for the use of their works. ${ }^{160}$ This regime has to be internationally harmonised, and must also consider the interests of every group involved, including creators, performers, users, technologists, states, and relevant industries. This legal framework should regulate the issues described in this work, but should be drafted in neutral terms so as to anticipate future challenges. It would apply whenever exclusive rights are difficult to implement or could have negative effects on society. This regime should not restrict fundamental rights, such as freedom of expression and communication, privacy and data protection, ${ }^{161}$ and should consider copyright in its complexity, taking into account its legal aspects, but also its philosophical, economic, and social aspects. ${ }^{162}$

\footnotetext{
${ }^{159} \mathrm{https}: / /$ search.coe.int/cm/Pages/result_details.aspx?ObjectID=09000016805cad04.

160 'Under conditions of the digital age a new social contract between creatives and audiences has to be negotiated, a new arrangement for the reciprocal creative contribution' by authors and by society', Grassmuck, V. [2009], Sustainable production of and fair trade in creative expressions, Research Workshop on Free Culture, Berkman Center for Internet \& Society at Harvard University Cambridge, MA, 23 October, cyber.law.harvard.edu/fcrw/sites/fcrw/images/Grassmuck_09-10-23_Free-Culture_Berkman_txt.pdf.. Also, Aigrain, P. (2008), Internet \& creation- Comment reconnaître des echanges sur l'internet en finançant la creation? (Inlibroveritas 2008). Available at www.ilv-bibliotheca.net/pdf_ebook_gratuit/internet_et_creation.pdf. English summary at www.creativecontribution.eu/? $\mathrm{p}=22$. See Dimita G. ,Copyright and Networking Technologies, Edward Elgar, 2019 Forthcoming.

161 On the importance of fundamental rights in the European legal framework, see Geiger, C. [2006], Constitutionalizing intellectual property law? The influence of fundamental rights on intellectual property in Europe, I.I.C. 371 .

162 This paragraph includes most of the suggestions from Geiger, C. [2010], 'The future of copyright in Europe: striking the balance between protection and access to information', [2010] 1 IPQ 1-14.
} 
Today, a considerable part of the content shared on the internet is protected by copyright and is not authorised. Copyright owners have significant difficulties in convincing users that they should pay for the works they download and access. ${ }^{163}$ Nevertheless, 'Copyright has adapted in the past; it will again'. 164

${ }^{163}$ Ficsor, M. [1996], Towards a global solution: the digital agenda of the Berne Protocol and the new instruments, in Hugenholtz, P.B. (ed) [1996], The future of copyright in a digital environment, Kluner. Walker-Sharpe [2002], Digital rights management, 18(4) C.L.S.R. 259, 261. OECD [2005], Working party on the information economy- Digital broadband content: music. www.oecd.org/dataoecd/13/2/ 34995041.pdf. [15/08/2010]. Strahilevitz, L.J. [2003], Charismatic code, social norms, and the emergence of cooperation on the file-swapping networks, 89 Virginia L. Rev. $505,581-2$.

${ }^{164}$ de Zwart, M. [1996] Copyright in cyberspace, Alternative Law Journal 266, 270. 